\title{
USING MIND-MAPPING AS A TRANSITION FROM RECEPTIVE TO PRODUCTIVE SKILLS FOR SECOND-DEGREE LEARNERS
}

\author{
Tran Thanh Thu* \\ Faculty of Language Education, VNU University of Languages and International Studies,
}

Pham Van Dong, Cau Giay, Hanoi, Vietnam

Received 28 October 2018

Revised 24 January 2019; Accepted 27 January 2019

\begin{abstract}
Mindmapping, as a powerful brainstorming tool, is gaining popularity in all fields of science. This article aims at suggesting various activities enclosed with explanations of how this useful utility can be applied for a smooth transition from receptive skills to productive skills while teaching English. As mind maps only date back to 1976, the article initially provides an overview into how to use them and how well they suit the group of grown-up learners. The third part of the article introduces the researcher's own organization of twelve academic themes throughout the learners' course. The most important part of the article involves an analysis of various examples of classroom mind maps as they are combined with various activities in classroom settings of various levels throughout the course, highlighting the shifting from one receptive skill to the corresponding productive skill with groups of learners' contributions to the maps. Last but not least, in the conclusion part, both the summary of the work and some recommendations would be presented about the challenges teachers may encounter and thus should expect during the implementation process.
\end{abstract}

Keywords: mind-maps, vocabulary, classroom implementation, challenges for teachers

\section{Introduction}

Receptive skills, also known as passive skills, include listening and reading skills and involve comprehension as the main goal while asserting their role as language input for the productive, or expressive skills they contrast with. With the recent approach on learning, the receptive skills are now being recognized as an integral part within the integrated learning method (Duquette, 1995).

While achieving communicative comprehension in receptive skills of listening and reading,

* Tel.: 84-1692920545

Email: thanhthu3108@gmail.com learners acquire both the source language and the information or news on certain themes, and thus build up their language competence on the language as well as their background on those themes. In the corresponding expressive skills a speaker or writer would make use of the knowledge of the language, comprising of pronunciation or spelling, meaning, the use and finally grammar, combining their background knowledge of the topic as well as their understanding of the context and culture.

In the meantime, current curricula are revolving around theme-based course books with integrated skills to support learners since "as the theme focus moves from self and home to community and work, the dramatic play 
area may change from the familiar child and household furnishings (doll, kitchen, etc.) to office, restaurant, or grocery store furnishings and props (cash registers, typewriters, etc.)." (Berry \& Mindes, 1993).

For adult learners in general, they are expected to have more background knowledge as well as life experiences than young learners. Nevertheless, the groups of learners conferred here in the research would be more complicated as they belong to the group of adult learners among whom the majority have already acquired a university degree and purposely chose English as the major for their second degree. Furthermore, as they are studying for the second degree while doing their job or continuing another course at another university, it is crucial to maximize the efficiency of the methods of learning to help them achieve the aims and objectives of the course and hence aid them to reach level $\mathrm{C} 1$ - the required level of proficiency for their second bachelor degree.

While acquiring adequate competency of advanced level is crucial, the groups of learners faced a lot of difficulties as not only do they have rather limited class time for their English major but they also face rather more limited acquisition of language items due to the mature age, as compared to younger learners. Though as mentioned above, they tend to possess the utmost advantages of life experiences and in-depth background knowledge across different fields of the current news and information, in many cases strong understanding of their previous majors.

Before further discussion, a brief overview of the main concepts in the research would be discussed as follows.

\subsection{Receptive and productive skills in language learning}

The two sets of skills requires (1) the encoding process in which the speakers or writers use the language to put forward their messages, using language items of their choice, and (2) the decoding process whilst the listeners or readers attempt to comprehend the messages or pieces of information basing on their own language competence and background.

Nevertheless, the reversed order would customarily be applied in language learning process as the decoding process involving receptive skills would come before the encoding process with their corresponding expressive skills, i.e. the order of mentioning when discussing all the four language learning skills should be (1) listening - (2) speaking, then comes the pair (3) reading - (4) writing.

Rather than aiming at readers as learners of the language, this section would aim at the side of the teachers/lecturers and hence focus on the terms and methodological notices during the teaching process.

In order for a set of communicative objectives in a communicative curricula to be accomplished, "the objectives should be experiental in nature, that is, they should make use of students' life experiences as the contexts in which to set meaningful communicative efforts," according to Tremblay et al (1990) and LeBlanc (1990), as cited in Duquette (1995, p.28).

Also in his book, Duquette(1995) suggests a sample model of procedure for vocabulary acquisition, involving brainstorm and classification. The purposes of the set of activities include increasing students' vocabulary in certain theme areas and during the process, involve students by letting them contribute their own real-life experience to the list of responses.

This report further enhances Duquette's model by using a mind map in stead of a list of responses for better visual aids and organization of the vocabulary items and ideas. 


\subsection{What is a mind map?}

Before mentioning its use in shifting from receptive skills onto productive ones for second degree learners, it is of relative necessity to introduce the concept and the use of the tool in language learning since the term is quite new, dating back only to 1976 as a creation of the infamous father Buzan.

A mind map, or the tool of mind-mapping can be defined simply as "a visual way of arranging information", as put up by Buzan (1974) in his popular book Use Your Head. From this point onward, the report would like to refer to Buzan as the creator of the useful tool that is gaining popularity in various fields of science including Medicine, Economics, Psychology, Cognition, etc.

Both the construction and the components of a mind map can be seen through the diagram below:

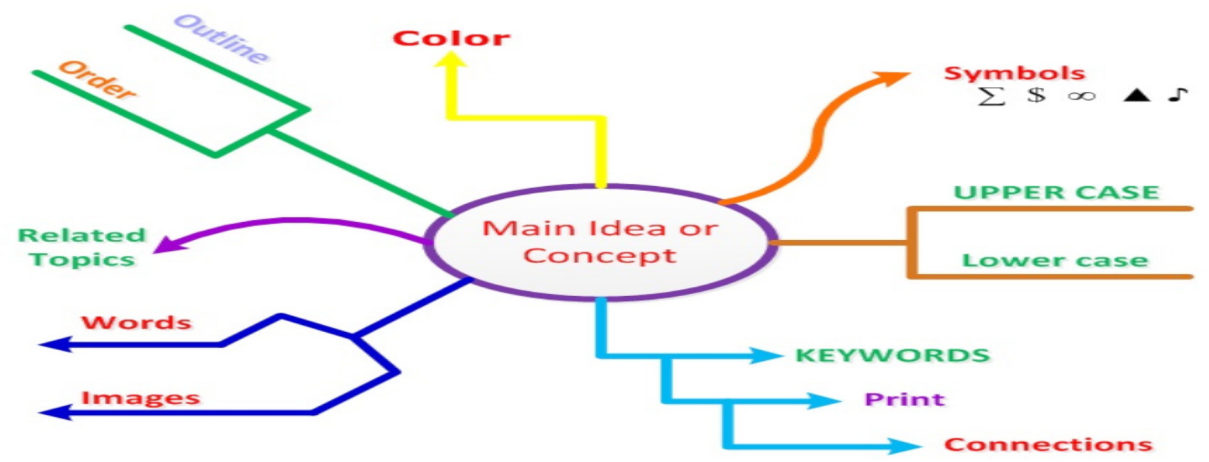

Figure 1. The components of a mind map with different color for each branch ${ }^{1}$

The diagram above clearly shows the concept or the central topic of discussion in the center. Pointed out from the balloon of the concept are numerous main ideas which are presented with different colors for both visual and intellectual purposes. Mind maps can also make use of different highlighting gears like capitalization or a highlighting pen itself. Various special symbols, visual aids of images and hand-drawn for better engagement of the brain would also be encouraged (Buzan, 2018).

A more modern definition of mindmapping is that of Guerro \& Ramos (2015):
"Mind mapping is a graphical technique for visualizing hierarchical connections between several

1 Source: http://thepeakperformancecenter.com/ educational-learning/thinking/mind-mapping/ items of information. Each item of information is written down and then linked by lines to the other pieces thus creating a network of relationships. They are always organized around a single central idea."

(Guerro \& Ramos, 2015: 3)

Then, a mind map can also be simply defined as a diagram created in the mind mapping process. Please have a look at one example of the mind map below (ideas developed by the report writer herself - the main points involves content of the research. 


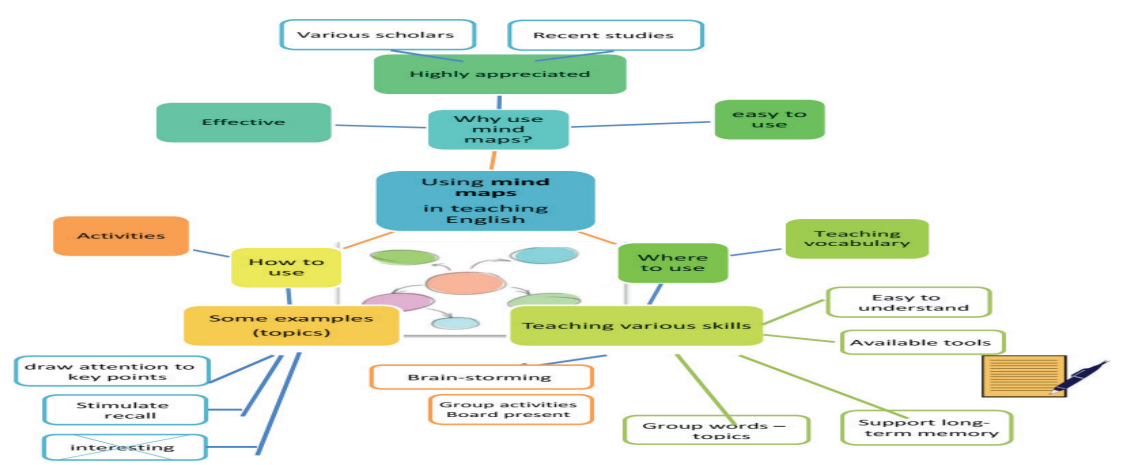

Figure 2. A mind-map of the organization of the whole section - using simple tools in Microsoft Words

\subsection{What have mind maps been used for?}

There have long been various studies on mind maps and though some of the earliest studies on language learning using mind-maps date back to the 1970s, (as stated above), the current years still see a lot of the term that can seemingly never go outdated.

Biggam (2015: 34) stated in his rather recent book that "it is difficult to find a simpler and more effective communication technique than mind-mapping. Mind-mapping is a superb way to collect and communicate your thoughts and ideas. It is used as a tool to crystallize your own thoughts and as a means of imparting those ideas to your supervisor as you progress through your dissertation." Hence, the writer of this research regards this tool a highly effective ones for students to build up their vocabulary and practice their writing skill at the same time.

In a more detailed sense, a mind map also "draw attention to key points and stimulates recall" (Guerrero \& Ramos, 2015: 27).

Compared to the traditional methods of brainstorming, including studious writing and linear note taking, mind mapping is said to be $15 \%-20 \%$ more effective in enhancing memory and improving learning. Task-based learning would become more accessible and problemsolving would be more efficient when mind mapping is used. "This phenomenon could be attributed on how the brain works" (Green, 2015).

\subsection{How to create a mind-map}

Traditionally mind-map makers only make use of simple tools of a pen and a piece of paper. It is also suggested that those who create mind-maps can use some pen colors for different main ideas.

One can also use more modern yet very simple computer tools in Microsoft Power point or Microsoft Word smart art to create mind maps using a computer, just like presented in Figure 1 (Guerrero \& Ramos, 2015).

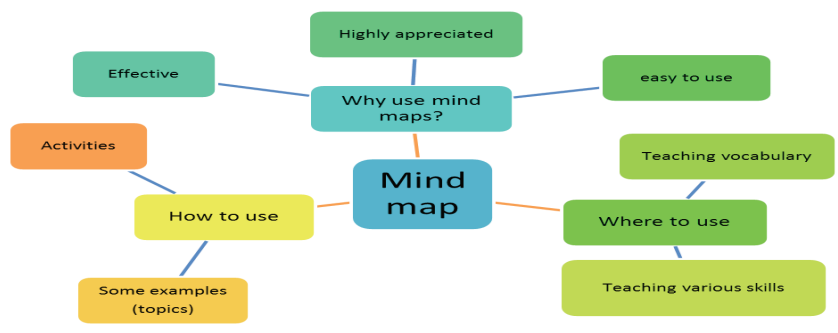

Figure 3. The organization of the introduction part 


\subsection{Using mind-maps in teaching English}

Belleza (as cited in Guerrero \& Ramos, 2015) stated that adult learners would learn most effectively "when they can form a connection between newly and previously acquired knowledge."

Hence, using the tool of mind-mapping comes forward as a proficient tool to organize and elicit the learners and thus encourage them to contribute to the mind maps as they brainstorm various topics of the themes introduced to them.

In all three stages of teaching and learning English; namely, (1) receptive stage, (2) productive stage and (3) revision stage, the tool can prove to critically benefit the learners, as displayed below.

\subsection{Using mind-maps to teach productive skills}

Mind mapping is considered to be a useful strategy to support students during writing tasks (Naqbi, 2011). As in writing, it enables students to make various attempts on ideas spread out on a sheet of paper. This way, it would definitely be much easier to see the equality among the ideas, and thus can adjust accordingly. They can combine, re-arrange them more freely than with an outline in the form of a list of bullets.
For speaking in particular, the vocabulary items which are new to learners can easily come with the corresponding phonetic forms to aid learners with pronunciation aspect of the words or phrases they encounter, whether for the first time or various times, i.e. both for introducing new vocabulary items and for revision purpose.

\section{Transitioning from receptive to productive skills for second-degree English- major learners}

\subsection{Mind map has long been proved to be a good organizational tool}

To begin with, the reporter would deliberately affirm that the use of Mind maps in organizing ideas and vocabulary items as a connection between receptive skills and productive skills for adult learners studying their second degree majoring English. As an efficient tool for organization, various mind maps has been used as a means of summarizing and hence benefiting learners' language learning through different themes and topics in books like "How to master skills for the TOEFL iBT Reading”, Level Basic.

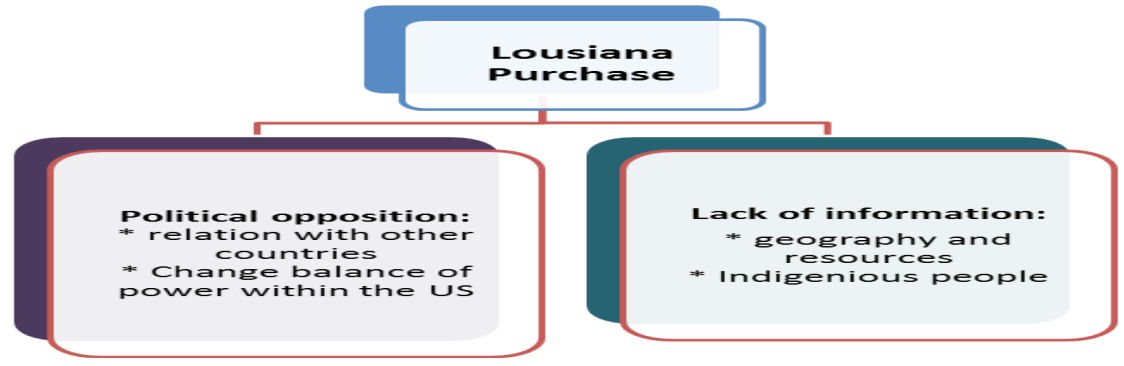

a. Louisiana Purchase 


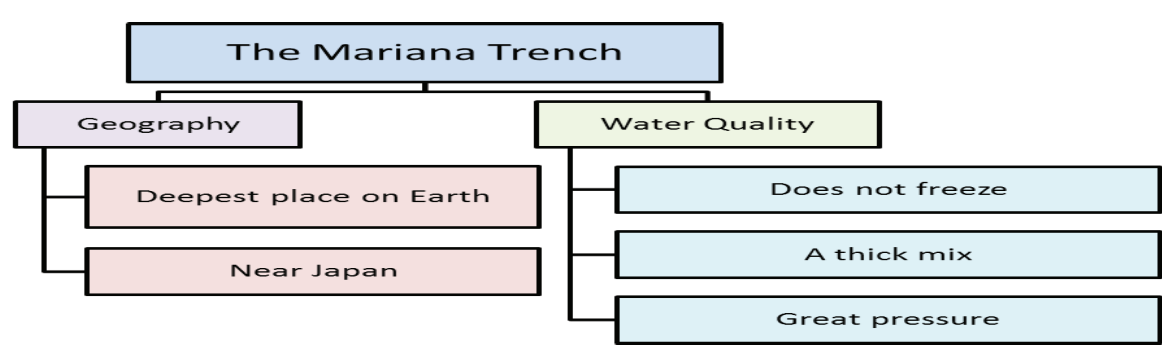

b. The Mariana Trench

Figure 4. Two examples of mind maps - content taken from "How to master skills for the TOEFL iBT Reading”, Level Basic (Hall, Milch \& McCormack, 2007)

\subsection{The nature of the group of learners}

General principles of teaching English to adult learning include reference to (1) their prior experience and knowledge, (2) their motivation in learning, and (3) their orientation to learning. (Knowles, Holton III, \& Swanson, 1998).

With the language learners who are achieving second degree, though English could be their major and the requirements are high, their motivation can be affected by their personal life, and in learning the language they have relatively clear purpose of acquiring the degree.

As for the first principle, which affect the choice of the instrument most, the adult learners having got the first undergraduate degree and many of them have been working for some time, it is safe to say that they have certain background knowledge and experience over young university learners or learners at a younger age.

\section{Implementing mind-maps in classroom settings for second-degree English-major learners}

As discussed in part 2, the use of mind maps can be implemented throughout the process of teaching English to the desired groups of student. This section will be dedicated to elaborate on the implement of mind maps in individual stages of teaching and learning English; namely, (1) receptive stage, (2) productive stage and (3) revision stage, though not as entirely separate parts but rather a section of integrated learning as a whole.

Although in the list of stages of teaching and learning English deliberated in the previous point this stage is put third, this stage is going to be discussed first as, conformably, within the focus of this point the stage would provide the whole table of twelve academic themes generated from various sources of test-preparation materials and thus provide fellow teachers while referring to this report with the whole picture of the themes and desirably help the readers comprehend the organization of the themes and consequently get the general idea of which theme to put a topic. This section emphasizes the important of helping students to build up language items following theme-based organizations. In using themes to help them study, the teacher has grouped all the topics into 12 main themes as follows. 


\section{Main themes (Academic tests)}
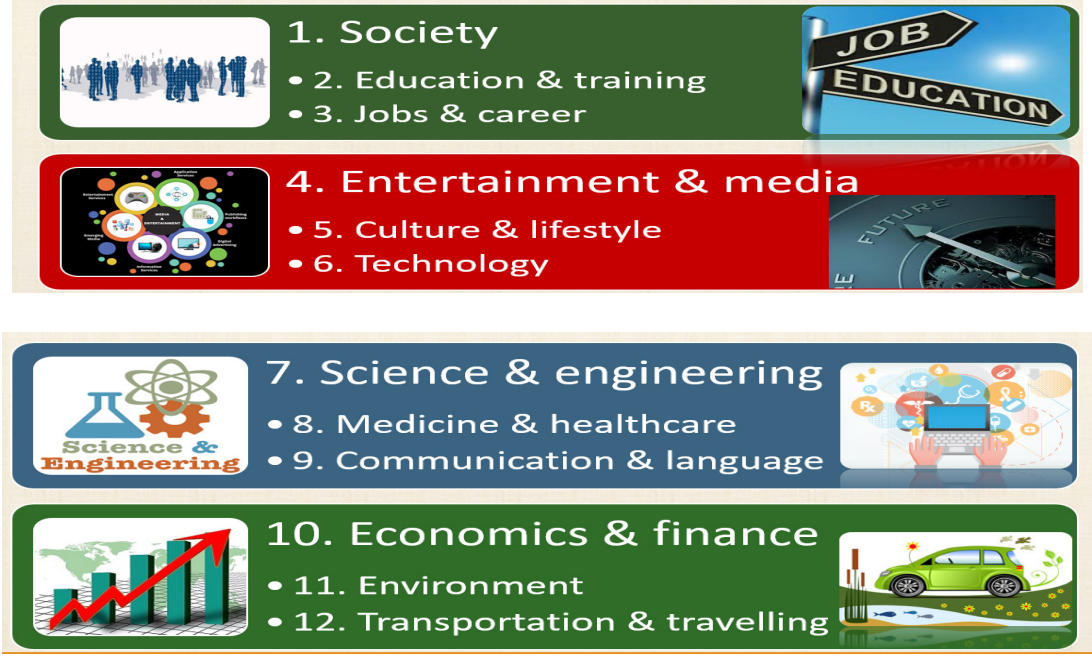

Figure 5. Classroom Microsoft power point slides part 1: The 12 themes in 4 groups in the revision for the VSTEP test, as taken from teacher's power point slides (2 slides)

The groups of themes are divided so that the components within one group and across all the groups can be as balanced as possible while still clearly show the prominent theme in each group. The first group of themes include three themes as follows:

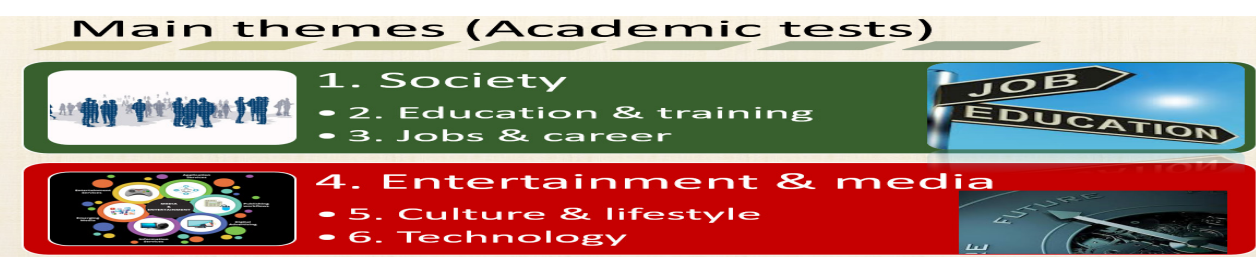

The relationship between the major topic of this group with each of the other two component can be presented as follows.

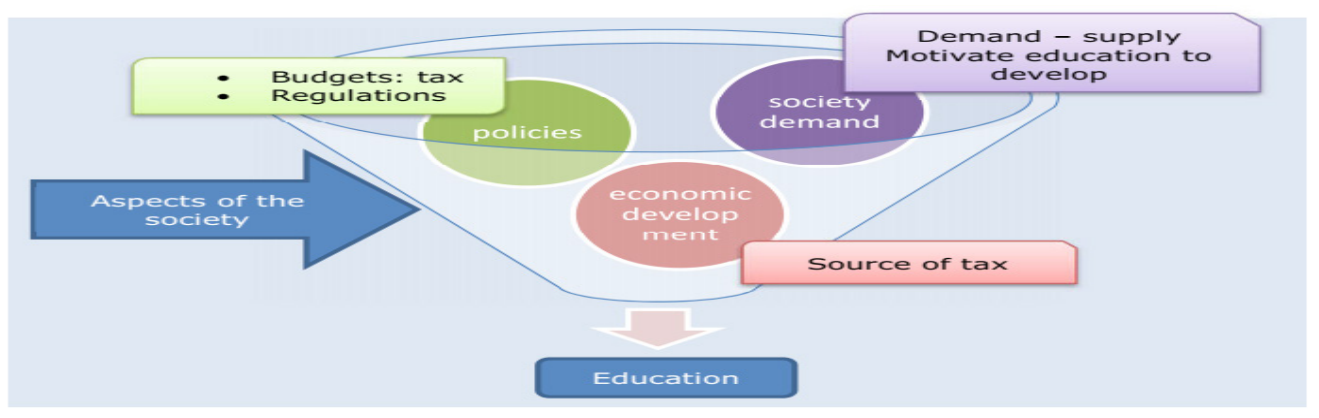

Figure 6. Classroom Microsoft power point slides part 2: The relationship between Society and Education, ideas elicited from students' discussions

This mind map is a relationship representation and while it was being implemented in real class setting, the learners were left time to discuss in groups and allowed to present their ideas in front of other groups. The teacher encourages each group to speak 
up and compare ideas, analysing the equality of main ideas, while explaining that some ideas can be misleading or a component of one another. It is important to state that the designed mind map the teacher put forward is only a suggestion, and if the class's analysis shows that some individual ideas can be supported logically and adequately, their ideas will be chosen.

As can be seen from the example above, a mind map maker can also make use of smart arts which are already available on simple tools of Microsoft Office like Microsoft Word and
Microsoft Power point, thereby it would not be much of a challenge for a lecturer to apply them.

With the relationship of the first two themes explained in details, the groups of learners seemed to get familiar with and this enhanced their motivation onto contributing more to the next relationships and thus the teacher will suggestably play the role of a facilitator rather than a knowledge provider.

The second relationship between the next pair of themes, which would be enlisted as Society and Jobs - career can be synthesized as follows:

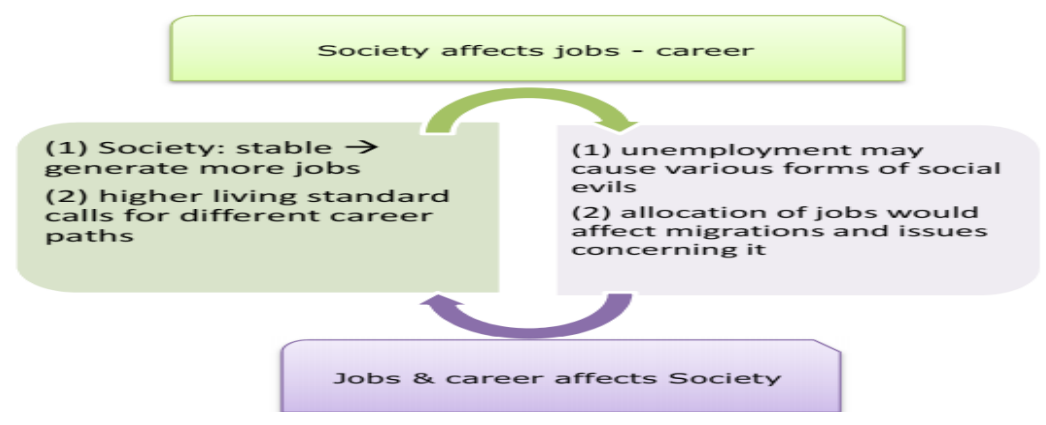

Figure 7. Classroom Microsoft power point slides part 3: The relationship between Society and Jobs - career, ideas elicited from students' contributions to the slides

With the last pair of themes in the first group, the learners can easily recognized as one of the most closely related pairs as they are composed of two interwened themes of Educations and Jobs - career.

The learners immediately recognize the role of education and training with the latter theme as a preparation for the future job, training skills and levels. As this pair of theme can be quite crucial in test preparation (due to its common application in various test items of all the four skills), it is quite significant to note learners of their role in academic topics and facilitate a debate sessions for two big groups of learners.

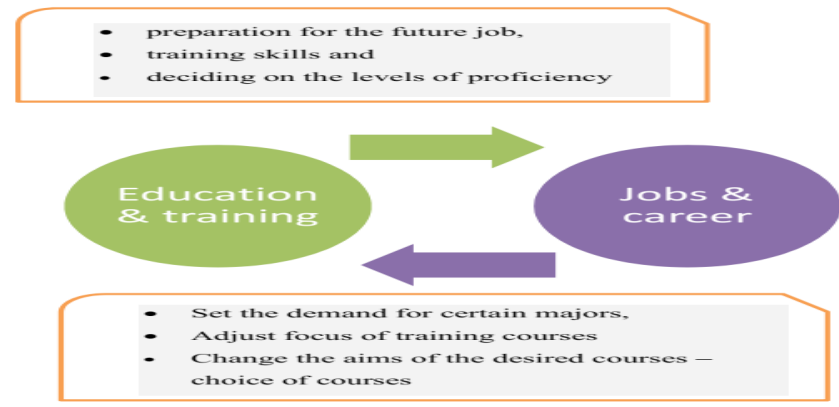

Figure 8. Classroom Microsoft power point slides part 4: The relationship between Education and Jobs - career, ideas elicited from students' debates 
The second group of themes are comprised of three following themes:

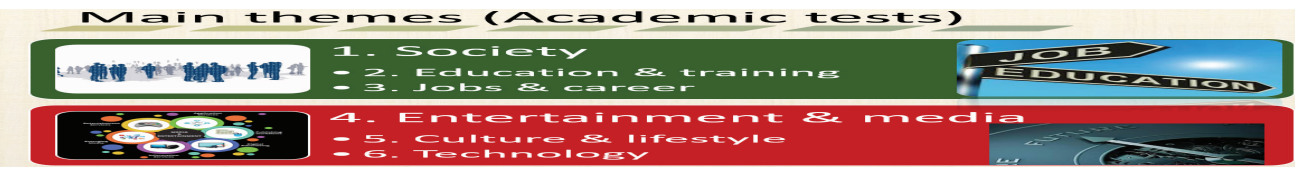

The first pair of themes include themes number 4 and 5 which would result in various test questions. With this group of four separate topics combined to create two themes, the teacher let learners brainstorm the relationship of more closely related pairs and guess possible test items or recalling related test questions from their memory. Learners could highlight the effects of social media on culture and lifestyle, and when the learners combine entertainment and lifestyle - while mentioning work - and they would have the topic of "work - life balance." Afterwards, the learners are required to make an outline for the test items - this is an integrated activity combining speaking and writing in which learners will choose main ideas together, and after deciding on their own main ideas, try to support the main ideas.

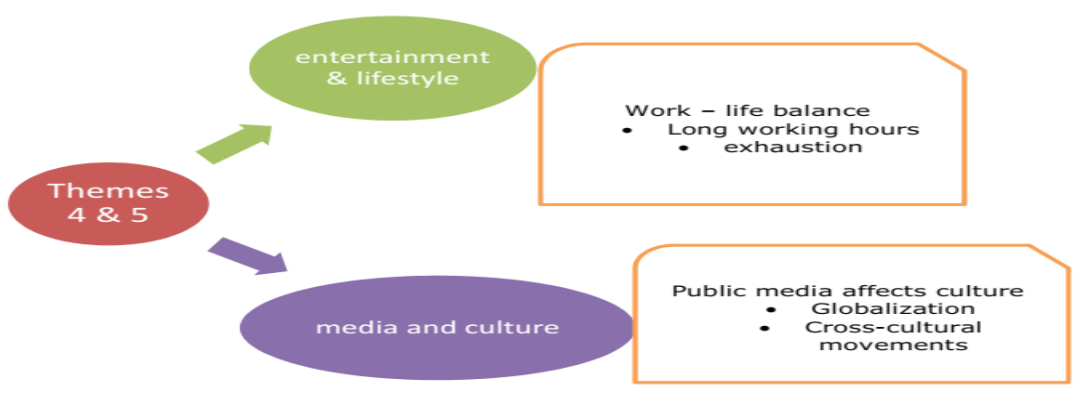

Figure 9. Classroom Microsoft power point slides part 5: The relationship between the fourth and the fifth themes, ideas elicited from students'guesses and discussions

Mind map can serve as both a useful learning tool and a beneficial test preparation instrument. At this point of the course, it is essential for the lecturer to mention the format of the speaking test, especially for the first English proficiency Practice course in which learners are mostly still unfamiliar with the format. In accordance with the changes in the format of VSTEP speaking test, with the mind map in the third part: Topic development, using different mind maps would certainly help learners get familiar to the organization of ideas in each topic and hence get the test done with less effort.

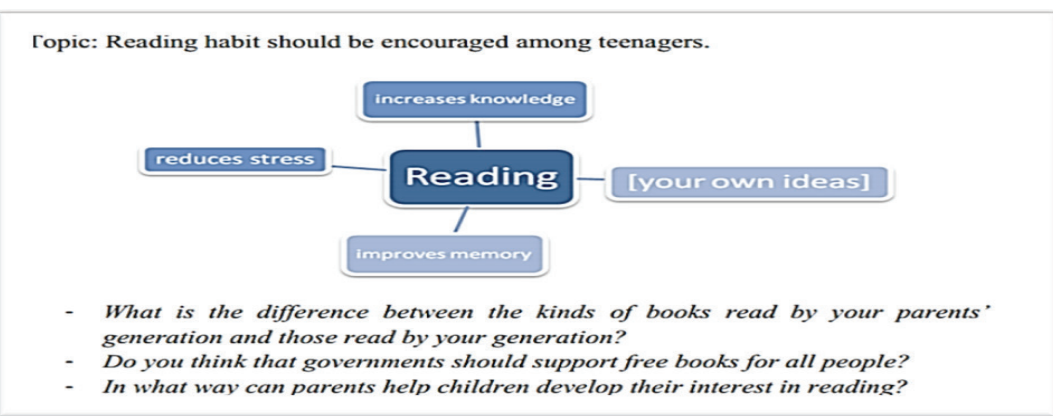

Figure 10. An example of a VSTEP speaking test, part 3; in the form of a mind map 
Regarding the pair of themes $4 \& 6$, it is of great importance to note that technology in this group can be a smaller theme but it can be the influential theme to a lot of the themes following it. It can even be an umbrella term for all the topics of communication, science, environment, and last but not least, economy. After discussing the relationship between the two themes, the lecturer also suggests allowing time for learners to brainstorm the effects of technology on all the themes mentioned above.

With all the mind maps above as illustrations, the researchers would like to move on to some other ways in which mind maps can benefit teachers while teaching English vocabulary within various topics.

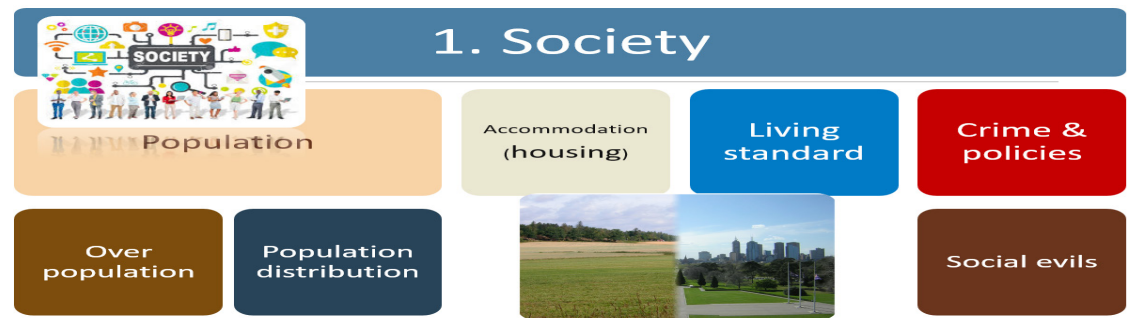

Figure 11. Classroom Microsoft power point slides part 6: brainstorming ideas within a big topic - teacher suggests and then elicits from students

Nonetheless, the researcher would like to emphasize that test preparation is also a crucial class time activities for the designed learners. And since it is a good instrument for summaries, revising lessons using a mind map would save time and effort, while still maximizing the results.

\section{Using mind-maps to transition from receptive to productive (expressive) skills}

As an illustration, this part of the research will present the real mind maps used in the two groups of skills, specifically receptive and productive skills.

Linear notes as a tool to take notes in skills while listening would be applied when necessary.

As the learners are quite sufficient in terms of critical thinking as well as background knowledge, and by applying one's own knowledge and experience in practicing new language items would enable and maximize the recollection of the items in the long term and thus would stimulate long term memory in a most definite way (Haggard, 1986).

Mind maps in the stage of inputting language items would mainly serve as a recap and checking organization tool, and from the organization of the ideas of the input language, learners would aim at the next stage of integrated learning between the communicative skills or non-communicative skills, i.e. they would organize ideas of the listening passage to prepare for their speaking session, recapping vocabulary items, trying to absorb written language expression from reading passages to try and use their main ideas or examples, or vocabulary items in their writing. 


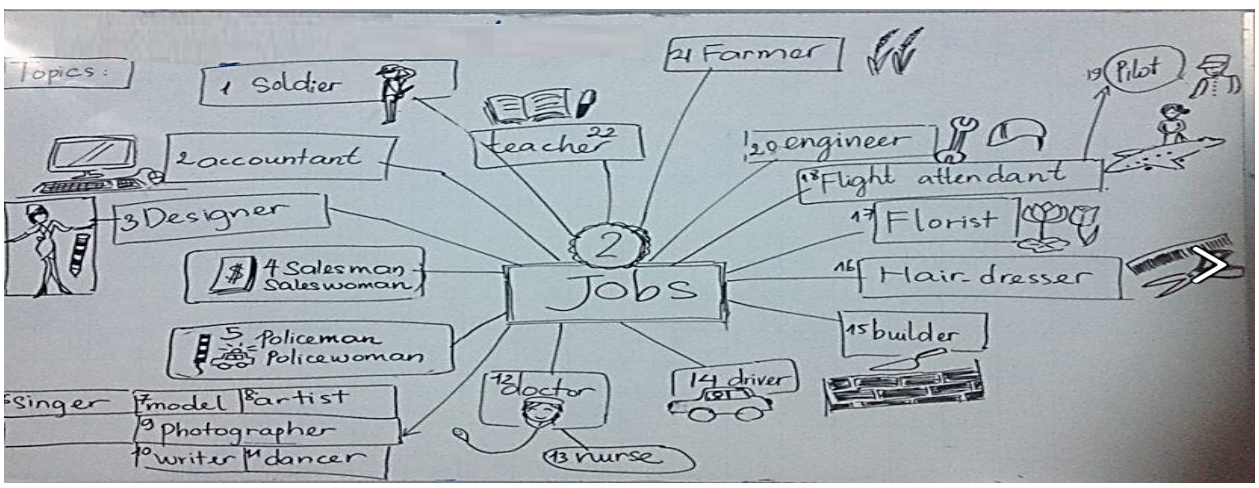

Figure 12. Picture of board mind map 1 - Jobs- elicited from a listening activity for learners of Level A2 - Pre-intermediate

Without a lot of colors provided by the computer tools, surprisingly most seconddegree learners find board activities very refreshing and user-friendly, though it may require the teacher to do a lot of drawing work to make up for it.

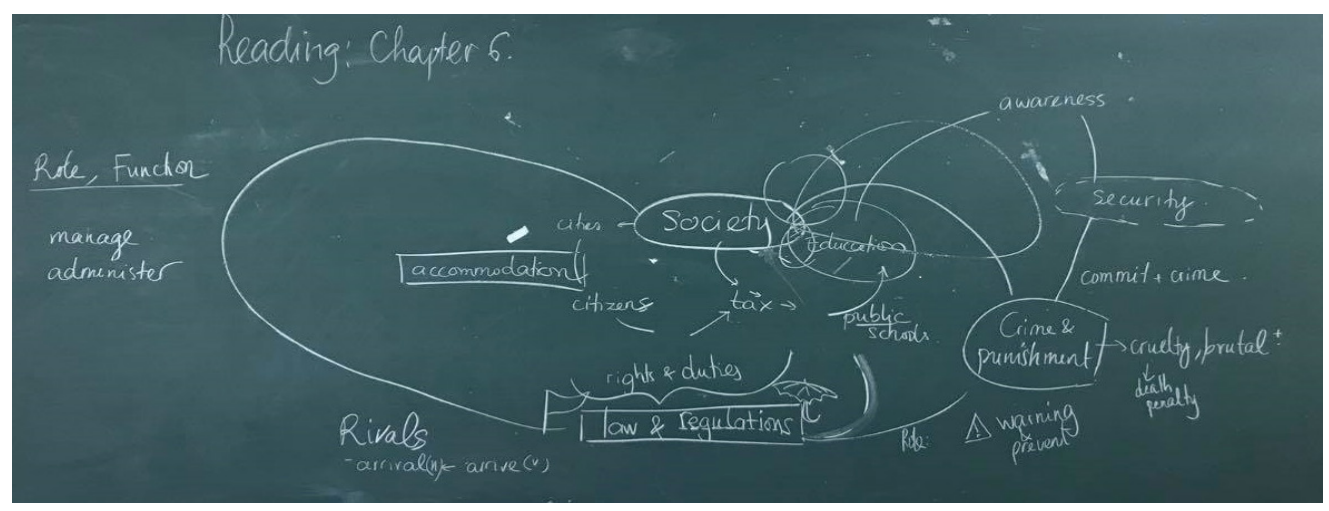

Figure 13. Board mind map 2: Picture of board mind map 1 - Jobs- elicited from a reading activity for learners of Level B2 - Upper-intermediate

Above is an example of a reading activity using the mindmap. Teachers can elicit key words from students and put them on the board, ask them to add more ideas from their memory - recapping the reading materials.

When transitioning from the receptive communicative skill to the productive communicative one or from the receptive non-communicative skill to the productive non-communicative one, mind mapping still seems to be quite new a recapping utensil. According to Wahba, England and Taha (2017), a teacher can construct a mind map combining the most important points of reading passages and instruct learners to add their own words to write in Arabic. This suggests the connection of the receptive skill and the productive counterpart using a mind map. While a mind map can be recycled from a recapping device of written articles to also serve as a framework for an essay.

Carter and McCarthy pointed out in their work in 2014 on the learning of vocabulary for production as only after mastering function words, substitute words and words of negative / confirmative construction can a learner move on to the next stage of productive skills. And the repetition of those language items can be seen through a lot of mind maps with the same kind of organization; for instance, the cause 
and effect organization with different themes.

In addition to the use of reiteration in the form of repetition for the sake of memorization (as in Halliday, 2014), the researcher would like to focus on the learner's needs and preferences when taking notes on the mind map eliciting. Since the learners could contribute their own ideas to the mind map, it could highlight to them that these are known information already, and they can relate to their real life experience to better memorize the items.

In yet the same work which has been readjusted from a 1984 work with the same title, Carter and McCarthy (2014) introduced the notion of vocabulary as a skill in which each learner is actively involved. That way learners would dynamically absorb the language items, and there would certainly be better chance for them to keep those vocabulary items in their long term memory.

Writing is a good illustration of the lack of organizational vocabulary among Vietnamese students. The skill has never seemed to be the most problematic one for adult learners or it is relatively safe to it is of common belief that Vietnamese students should have more problems with listening and speaking, or communicative skills. Nevertheless, results of various End-of-term test papers in which students left the writing session blank raised a question to the researcher as a teacher of English as what the reasons behind the incident are. As it turned out, the learners all found the amount of time allocated for the End-of-term test quite adequate, yet they have absolutely no clue what to write with the topic whatsoever. Their reading result was adequate for their level, though, which means their vocabulary was not too bad but they are still unclear about how to write, what to write within the quite adequate time they have. This suggest the loose connection of the receptive skills and the productive skills as they cannot make use of the expressions acquired from their reading to organize a writing passage, or even the first step of brainstorming.

In other words, the questions would be put as why with the allocated amount of time they could come up with no or hardly any language produce to mark for; secondly, what could be done about it, and how. Then their usefulness should also be revisited once the method has been implemented.

Furthermore, with the group of participants being second-degree learners, they have some specific traits of adult learners as being

It all comes back to the direct and yet ultimate aim of teaching English which is effectiveness, therefore the lecturer wanted to hear from her students first, what are their reasons for not being able to generate hardly any relevant language product at all, and the answers come down to the following major reasons: (learners can choose more than 1 reasons)

Top reason: Students think too sophistically and find it impossible to express themselves in English. This is especially common for second-degree learners as they have already acquired certain level of background knowledge in various fields.

Reason 2: They are unable to search for language in the topic given in the test. They know the language within the input skill, in this case reading skill, but when they have to face an output skill of writing, their English competence is still inadequate.

Reason 3: Students are obsessed with writing beautifully and in length. This is a matter of thinking to solve, as students insist on using their precious time writing unfinished "perfect drafts."

Reason 4: Their grammar is inadequate and since they are so afraid of writing anything wrong, they do not dare to write anything at all. These students find making incorrect sentences wrong, even sinful so they do not dare to write when they are not certain. This the researcher finds a rather 
interesting reason when she interview in depth with some of the students.

The reasons are clear and all are primitive, with the number of students confirming the top reasons reaches $95 \%$ or above, there should be no question whether or not to take some measures on this, the questions should be what to take and how.

For these matters, the researcher has worked hard to find out a solution to a more effective way of teaching productive skills in her class with the lack of output vocabulary, help students get more active and motivated and help them get used to speak or write with an outline for brainstorming.

Upon researching about various methods to learn vocabulary and to activate learners' writing capability, the teacher has come up with the method of using mind maps to teach her students how to organize vocabulary items in a topic, organize ideas in a piece of writing, as well as being able to visualize their thinking in order to be more critical and concrete. As this special group of learner have very high requirements of ultimately reaching level $\mathrm{Cl}$, learning the method would help them build up and add up their vocabulary bank in an utmost natural way and help them build up long term memory.

Since Suyanto (2010) came to the conclusion that "mind-mapping technique is more effective than modeling technique to teach writing for the seventh grade students of junior high school", other modern teachers who share the same opinion includes Amstrong (2003) who states the importance of mind maps in generating ideas and building thinking traits, and Scott, Scott, \& Webber (2015) who claimed that the method help students pull together all their ideas (p.70).

With the changes in the syllabus, students have a theme for each week, (Faculty of English, University of Languages and International Studies, Vietnam National University, Hanoi, 2015) using mind maps seems to suit the situation better than the listing form as mind maps help learners see the whole picture of the topic under discussion (Amstrong, 2003).

The first example here is about the topic of jobs. Within a short time, the learner has to get used to both the vocabulary items they could think of and some more from their peers, which can be quite difficult for them to memorize. With the particular group of adult learners who may also have a job and a family to take care of, it is best for them to maximize the efficiency and learn the items fast. In the picture above, the lecturer actually drew some fruits and even a coconut tree to help her learner memorize the items better. If other teachers are not as confident in drawing, it's for the best to prepare flash cards to aid with the memorization.

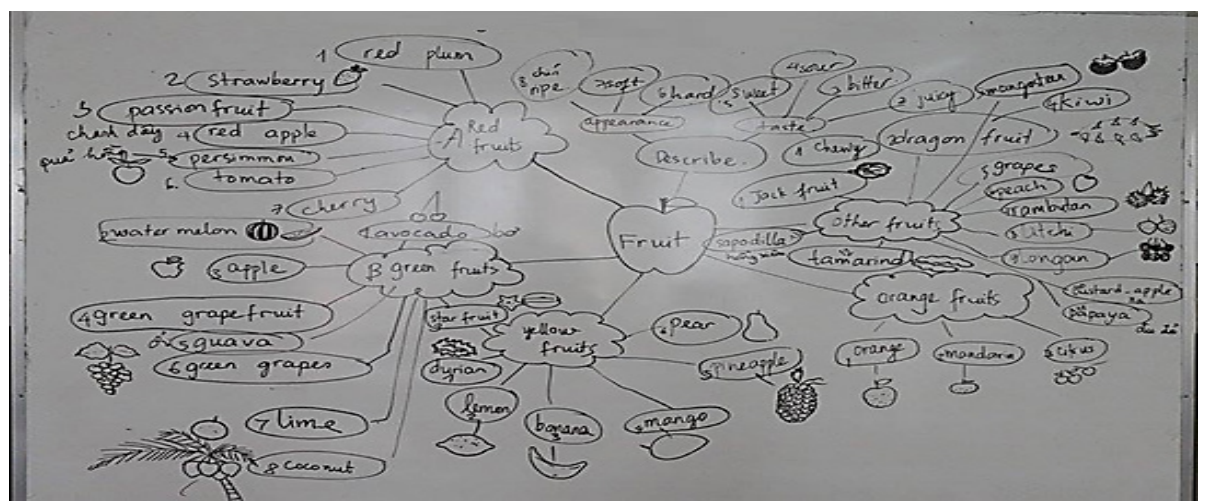

Figure 14. Picture of board mind map 2 - Fruits- elicited from learners learning the course of Level A2 - Pre-intermediate 
With the nature of this topic being the names of different kinds of fruit, it is useful to give learners a way to classify fruits, i.e. according to colors (ideas taken from the mind map on the internet, shown in the picture on the next page). The teacher then elicited learners' vocabulary of the kinds of fruit they know and help them note on the board. Images or drawings also serve as motivators to encourage learners to study more efficiently.
It is crucial that the learners get to contribute to the map, since a sense of contribution would also be another motivation. Moreover, when the teacher keeps on giving out the main ideas, and the details as well, the ultimate goal of a mind map of organizing own ideas would be left out. This is why the mind map has to be done on the spot while internet materials are available and ready to be used in the classrooms with projectors, all available in the university.

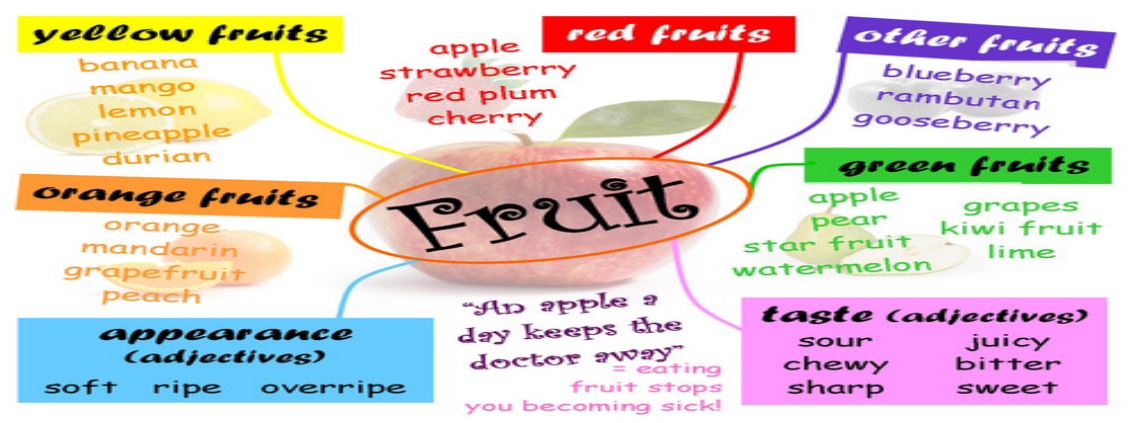

Figure 15. A mind map from the internet to aid teachers while preparing for the lesson ${ }^{2}$

With proper citation, all these mind map can be of excellent use to revise quickly all the vocabulary items the learners already encountered or came up with in the first time, and it is inevitable that they have revision to enhance the introduced expressions for longterm memory build-up (Halliday, 2014).

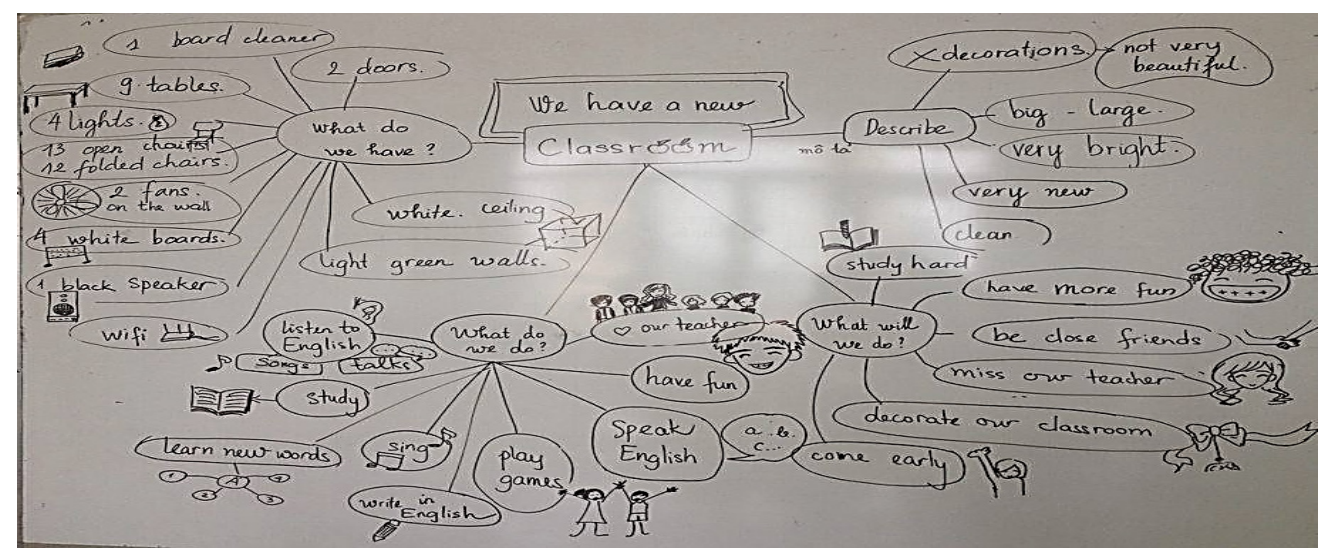

Figure 16. Picture of board mind map 3 - describe my new classroom - a writing activity of Descriptive paragraph

2 Source: https://www.tes.com/teaching-resource

/fruit-mind-map-6451788 
With this topic, the teacher had to aid learners with the key questions to ask about the topic. For some of the questions that learners could think of themselves, the lecturer instructed them to have a relationship among/between their ideas: chronological order, spatial order, causes - effects, or trying to sequence the ideas in a logical way.

From this instant, it is useful to note that implementing this useful modern tool would mean a lot of hard work to the side of the teacher as not only do they have to prepare for a lot of materials and may have to search for ideas for categorization from other mind maps on the internet, they also have to master eliciting skills, which means dealing with, helping learners organize their random ideas into the map, explaining to them the reason why that particular supporting idea should belong to that idea, and may have to help them order the ideas most definitely immediately.

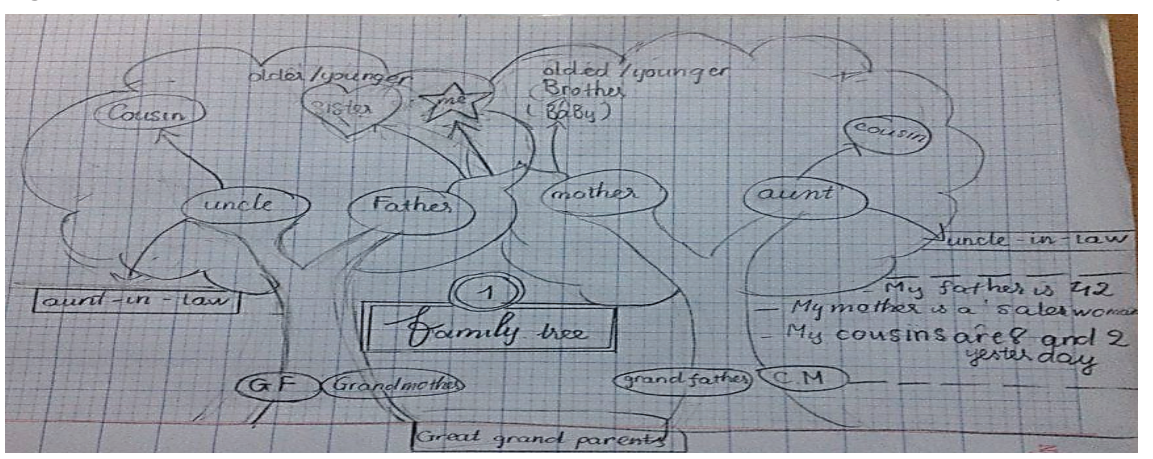

Figure 17. Picture of mind map 5 - Family tree (drawn by a learner) in A1 Level - Elementary

The result can be highly pleasing. The picture above is from a learner. Some of them can follow the instructor and draw very creative map which implies their high motivation in learning the language.

The mind maps are integrated with images to motivate learners to study.
With a normal setting in class, the following mind map can be a good example of a mind map made used of the white chalks and green board in all classrooms, which can be served as a substitute for the slideshows when there are technical problems.

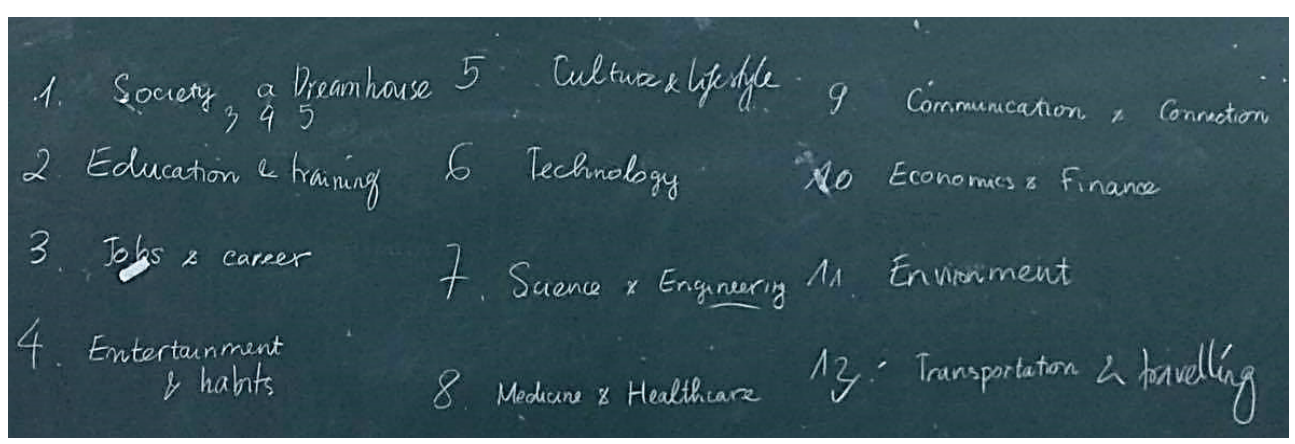

Figure 18. Board photo of activity in class (number 1): Eliciting and suggesting main themes for learners of Level B1 - Intermediate 
For instance, with a writing question with the test question: 'What do you think of this statement: "People nowadays are more dependent on technology.",' the teacher asked learners to find the key words and work together in small groups of 3 or 4 and discuss how they should develop ideas and add more vocabulary items on to the map. The following is a good example of a group who have done an excellent job.

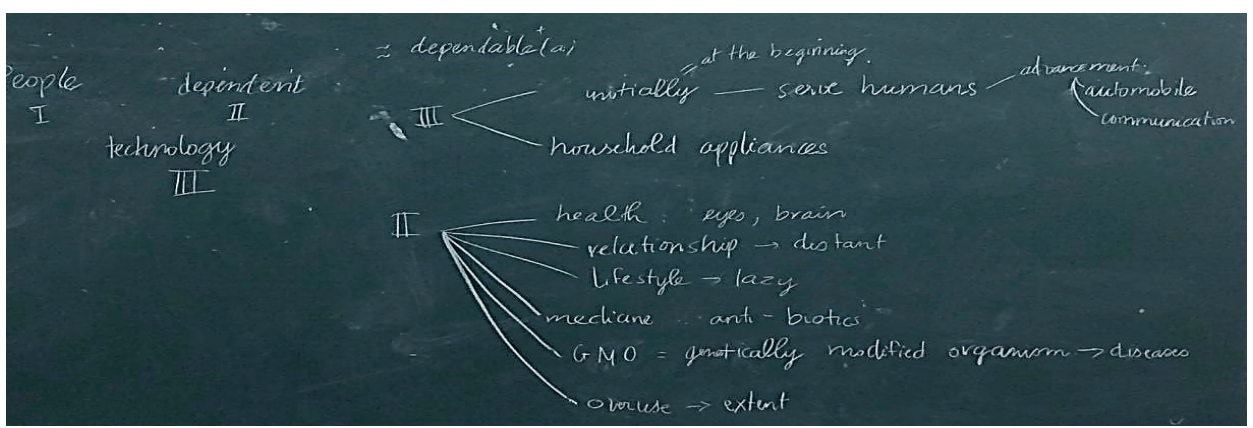

Figure 19. Board photo of activity in class (number 2): Writing skills: Group work for learners of Level B2 - Intermediate

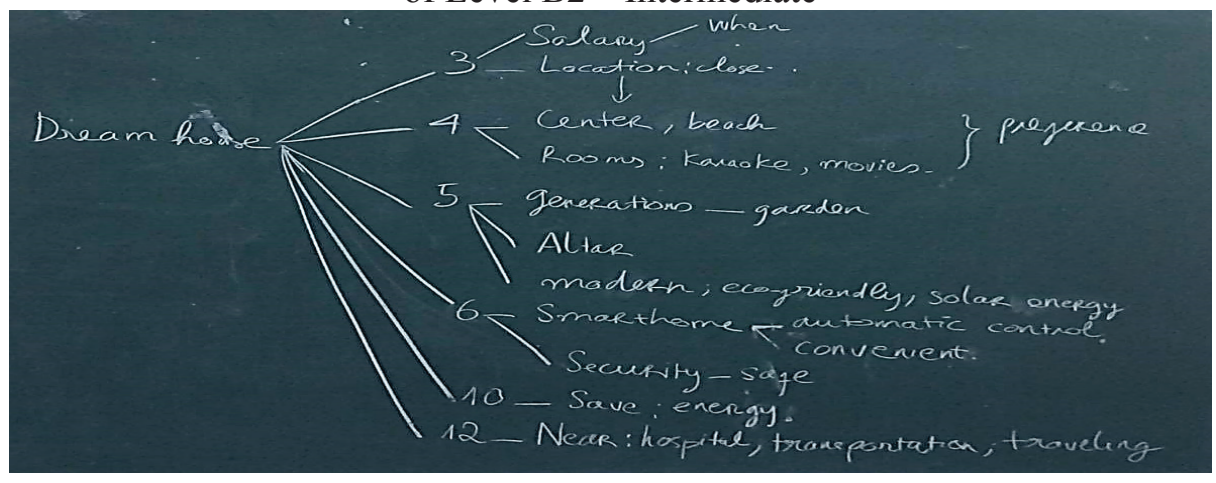

Figure 20. Board photo of a speaking activity in class (number 3): Writing skills: Group work for learners of Level B2 - Upper-intermediate

In this activity, learners have an inquiry of matching their supporting ideas with the big themes the vocabulary items of which can be used in their speeches. The numbers 3, 4, 5, $6,10,12$ can actually serve as suggestion for students of lower level: before they can come up with ideas, the teacher can suggest them think about the main themes they have learnt and try to connect the topics of the questions to the main themes.

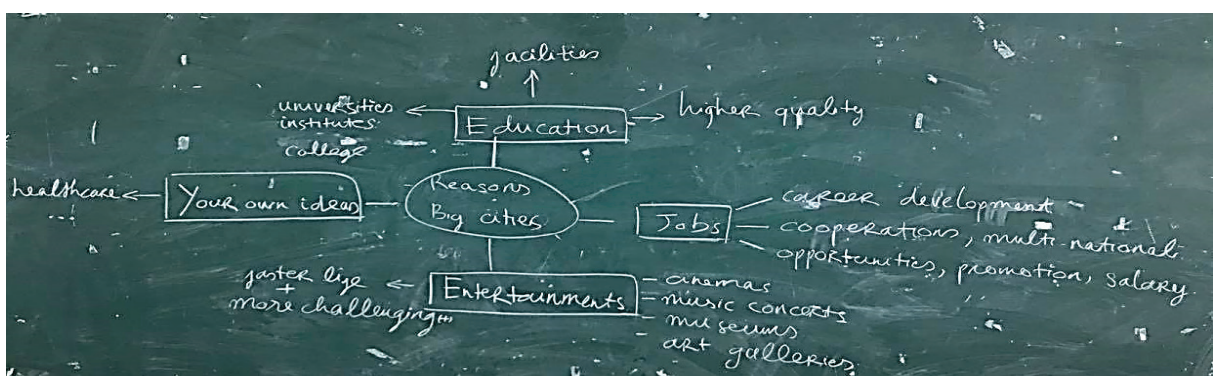

Figure 21. Board photo of a speaking activity in class (number 3): Writing skills: Group work for learners of Level B2 - Upper-intermediate 
Within the speaking lesson, this activity can actually be a good example of a test preparation one. The core mind maps are actually from a real speaking test, part 3, with the topic of "there are several reasons why people choose to live in a big cities". This activity is a class activity with a student playing the role of the secretary. Anybody in the class can contribute, and the teacher would correct or make comment when necessary.

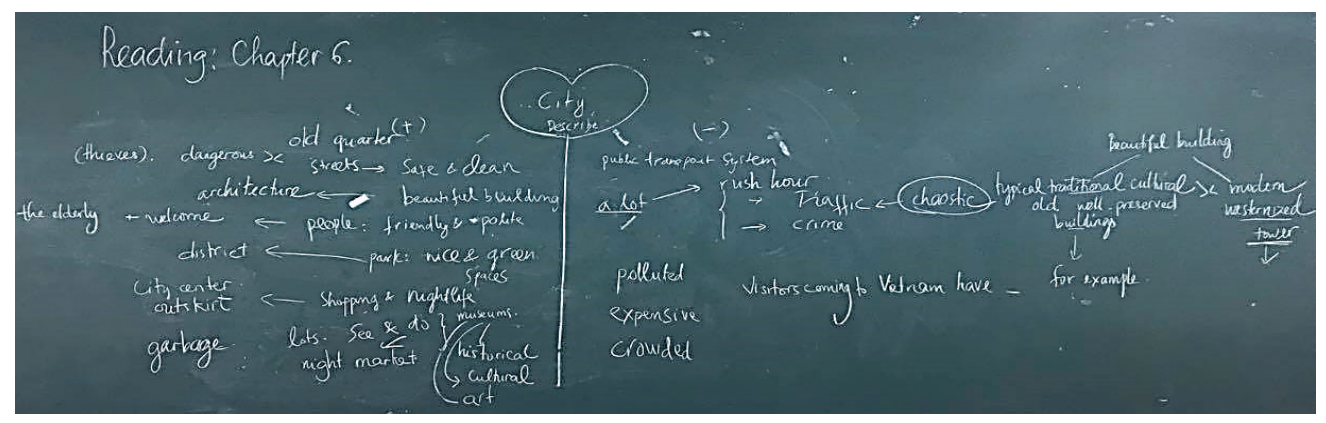

Figure 22. Board photo of activity in class (number 3): Writing skills: Group work for learners of Level B2 - Intermediate

This is an example of a mind map playing the role of the transition from Reading (a receptive skill) to Writing (the corresponding productive skill). Learners can make use of the language items they could remember from the previous activity and contribute to it using their own knowledge and experience. Relating to themselves was highly encouraging as can be observed in the classroom.

With the kind of organization of comparing and contrast, it is beneficial to note the students that they may have to face the same structures in all the four skills and it is safer to brainstorm a mind map so that they can organize their ideas better, as in VSTEP speaking test they also have one minute each to prepare for part 2 and part 3 of the test. As the ideas are so clear, the teacher here can play the role of a participants and allow the learners to have more freedom in deciding their ideas, suggestions and corrections may be provided afterwards as feedback.

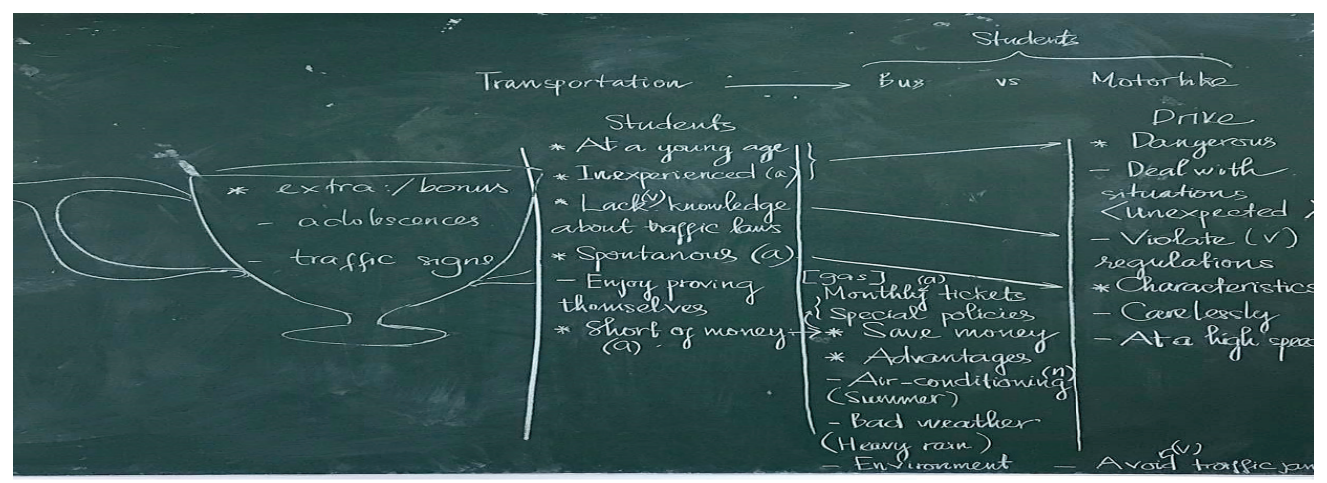

Figure 23. Board photo of activity in class (number 3): Writing skills: Group work for learners of Level B2 - Intermediate 
With the type of questions which require learners to compare two kinds of means of transport, the teacher may choose to suggest them focus on the nature of the subject (in this case 'young people'). It can be seen from the picture that on the top they actually indicate clearly not only the key words but also the relationship among the items, using very good symbols. This table is also a form of mind map but its format was adjusted to fit the requirements of the lesson: choose the appropriate supporting idea for each main idea, indicating the appropriateness with arrows.

\section{Conclusion}

This part of the article will demonstrate the summary and provide some suggestion for fellow teachers while applying this tool in their teaching.

In applying the method to various groups of students of all the levels from A1 to $\mathrm{C} 1$, the question was not whether the teacher should make use of the useful tool; rather, it naturally shifted to the question of how should be applied in specific situations. The fourth part of this article was dedicated to achieve that.

As beneficial as it is, when applying the tool to classroom setting, there are certain challenges for teachers throughout the process. First and foremost, they need to be prepared for all kinds of unexpected responses from their experienced learners and thus searching the internet in advance and constant build-up of background knowledge on various topics would be obligatory.

Secondly, they may have to be ready for all kinds of questions, most of them concerning the reasons why they should put a supporting idea or an example into a branch of main idea. This requires high level of critical thinking and logic.
Another challenge is the required flexibility and quick response from the side of the teachers. There are often more than 20 students in one group and the teacher has to elicit, analyze, select ideas, and organize them into the correct branches, while determining whether or not the learners could come up with proper main ideas, persuading them to use certain supporting details and not others.

Though the tool can be rather challenging, applying them in real classroom setting can be very rewarding as it inspires both teachers and learners to be creative and thus stay motivated throughout the process. The reporter highly recommends the use of this useful tool in a large scale.

\section{References}

Amstrong, T. (2003). The Whole-brain Solution: Thinking Tools to Help Students Observe, Make Connections and Solve Problems. Ontario: Pembroke Publishers Limited.

Berry, C. \& Mindes, G. (1993). Planning a Themebased Curriculum: Goals, Themes, Activities, and Planning Guides for $4 s$ and $5 s$ (pp. 10-11). New York: Good Year Books Publisher.

Biggam, J. (2015). Succeeding with Your Master's Dissertation. Ontario: Open University Press McGraw-Hill Education.

Buzan, T. (1974). Use your head. London: British Broadcasting Company Publisher.

Buzan, T. (2018). Mind Map Mastery: The Complete Guide to Learning and Using the Most Powerful Thinking Tool in the Universe. London: Watkins Publishing.

Candlin, C. N. (1988). Vocabulary and Language Teaching. London: Longman.

Carter, A. \& McCarthy, J. (2014). Vocabulary and Language Teaching. London: Routledge.

Faculty of English, University of Languages and International Studies, Vietnam National University, Hanoi. (2015). Schedule for General English 1 (Semester I-Academic Year: 2015 - 2016).

Green, F. (2015). Mind Mapping: Step-by-Step Beginner's Guide in Creating Mind Maps!. Bloomington: Booktango Publishing.

Guerrero, J. \& Ramos, P. (2015). Introduction to the applications of mind mapping in medicine. Toronto: CreateSpace Independent Publishing. 
Haggard, R. (1986). The vocabulary self-collection strategy: Using student interest and world knowledge to enhance vocabulary growth. Journal of Reading, 29(7), 634-642.

Hall, T., Milch, A. \& McCormack, D. (2007). How to master skills for the TOEFL iBT Reading, Basic. Seoul: Darakwon Publishing.

Halliday, M., \& Matthiessen, C.(2014). Halliday's Introduction to Functional Grammar. London: Routledge.

Knowles, S., Holton, F., \& Swanson, A. (1998). The adult learner: The definitive classic in adult education and human resource development. Houston Tex: Gulf Pub. Co.

Lessard-clouston, M. (2013). Teaching vocabulary. English Language Teacher Development Series. California: TESOL International Association.

Naqbi, S.A. (2011). The use of mind mapping to develop writing skills in UAE schools. Education, Business and Society: Contemporary Middle Eastern Issues, 4(2), $120-133$.
National Education Union. (2018). Fruit mind map. Retrieved from https://www.tes.com/teachingresource/fruit-mind-map-6451788

Scott, S., Scott, D. E., \& Webber, C. F. (2015). Leadership of Assessment, Inclusion, and Learning. New York: Springer Publisher.

Suyanto, A. (2010). The effectiveness of Mindmapping to Teach Writing Skill Viewed from Their IQ (An Experimental Study in the Seventh Grade Students of SMPN 1 Prambon in the Academic Year 2009/2010). Graduate, Sebelas Maret University, Surakarta, Indonesia.

The Peak Performance Center (2018). Mind mapping. Retrieved from http://thepeakperformancecenter. com/educational-learning/thinking/mind-mapping/

Wahba, K., England, L. \& Taha, Z. (2017). Handbook for Arabic Language Teaching Professionals in the 21st Century. London: Routledge.

\title{
ÚNG DỤNG CÔNG CỤ SO’ ĐỒ TƯ DUY VÀO HÊ THỐNG HÓA CẢC YẾU TỐ TỪ VỰNG THEO CHỦ ĐỀ CHO HỌC VIÊN VĂN BẰNG HAI
}

\author{
Trần Thanh Thư \\ Khoa Đào tạo và Bồi duoõng Ngoại ngũu, Trường Đại học Ngoại ngũu, ĐHQGHN, \\ Phạm Văn Đồng, Cầu Giấy, Hà Nội, Việt Nam
}

Tóm tắt: Sơ đồ tư duy, một công cụ hưu ích cho người học, đang ngày càng được ứng dụng rộng rãi trong nhiều ngành khoa học. Chính vì vậy, mục tiêu của bài viết này là chia sẻ các hoạt động áp dụng sơ đồ tư duy vào việc dạy từ vựng tiếng Anh. Trước tiên, bài báo sẽ có những giới thiệu tổng quan cách sử dụng sơ đồ tư duy cũng như cách áp dụng trong các hoạt động gắn với từ vựng. Bài báo sẽ trình bày cách chia nhóm đối với mười hai chủ đề lớn bao trùm nội dung trong chương trình học của học viên. Phần tiếp theo, cũng là phần quan trọng nhất, sẽ đưa ra những phân tích về các sơ đồ tư duy đã được sử dụng trong lớp học cũng như cách kết hợp chúng với các hoạt động cụ thể trong giờ học, qua đó, có những đề xuất để giải quyết các vấn đề mà người dạy có thể gặp phải trong quá trình áp dụng.

Tù khóa: sơ đồ tư duy, từ vựng tiếng Anh, việc áp dụng trên lớp học, thách thức đối với giáo viên 